PAEDAGOGIA ChRISTIANA

I/21 (2008) - ISSN 1505-6872

Andrzej Kociołek

Łódź

\title{
Budowanie wspólnoty Kościoła w sytuacji społeczeństwa ponowoczesnego
}

Kościół jest tajemnicą Chrystusa i wszelka moc pochodzi z jego więzi z Chrystusem. Jego zadaniem jest dbanie, aby światło Chrystusa jaśniało na obliczu Kościoła. Ponadto Kościół jest sakramentem, a więc znakiem i instrumentem wspólnoty człowieka z Bogiem. Kościół jest ludem mesjanistycznym, który powołany został do realizacji dzieła zbawienia i zapoczątkowania Nowego Stworzenia. Kościół jednocześnie składa się z grzeszników i dlatego zobowiązany jest do ciagłego oczyszczania siebie. Z tego względu jego życie stoi pod znakiem tajemnicy Krzyża i tajemnicy Zmartwychwstania. Z nauki Soboru Watykańskiego II o Kościele, jako tajemnicy Chrystusa i znaku jedności z Bogiem, wynika, że budowanie Kościoła polega nie tyle na reformie struktur, co na realizacji powszechnego powołania do świętości. Zatem w tworzeniu i budowaniu Kościoła należy zachować i rozwijać ducha pokuty, modlitwy, adoracji, miłości i sprawiedliwości ${ }^{1}$. Mając na uwadze ogólną naukę soborową na temat Kościoła, pragniemy zwrócić uwagę na znaczenie tworzenia, budowania i rozwijania grup katechizowanych jako wspólnot wiary. Ważną sprawą w tworzeniu i budowaniu wspólnoty Kościoła jest także kształtowanie soborowej świadomości o Kościele oraz wychowanie świadomości poczucia przynależności do Kościoła u katechizowanych.

\section{Grupa katechizowanych jako wspólnota wiary}

Masowość, sekularyzacja i technicyzacja współczesnego życia wprowadzaja coraz większą pośredniość kontaktów międzyludzkich, jednocześnie stwarzają

* Ks. dr Andrzej Kociołek, wykłada katechetykę w Instytucie Teologicznym w Łodzi.

${ }^{1}$ Por. W. Łydka, Kościót, w: A. Zuberbier (red.), Stownik teologiczny, t. I, Katowice 1998, s. 257-261; A. Zuberbier, Współodpowiedzialność świeckich w zbawczym posłannictwie komuniiKościoła, AK 114 (1990), s. 388-396; J. Stroba, Synod Nadzwyczajny, Katecheta 30 (1986), s. 99. 
ogólną i wyraźnie zaznaczającą się potrzebę nawiązywania bliskich więzi osobistych, przyjacielskich, umożliwiających szczerą wymianę poglądów, współkształcenie i współdziałanie². Warto zauważyć, że rodzina, która winna gwarantować wychowanie chrześcijańskie swoich dzieci i w ten sposób zapewniać ciągłość parafii, traci obecnie niektóre z tych zdolności. Trzeba zatem otwierać możliwości nowym, uzupełniającym ośrodkom grupowym, w których dzięki chrześcijańskim przekonaniom, dążeniom i zachowaniom mogą być zakotwiczone osobowości apostolskie. Podejmowanie takiej formacji przysporzy owym grupom czy wspólnotom stopniowo odpowiedniej wiedzy, przywiązania, świadomości, a zarazem i odpowiedzialności, co z owej struktury, z owej grupy czy wspólnoty lub stowarzyszenia uczyni zbiorowy podmiot ${ }^{3}$.

Katecheza wywodzi się ze wspólnoty Kościoła, która jest jej podmiotem i miejscem, i powinna do niej prowadzić, wychowując do budowania wspólnoty 4 . Katecheza jest zatem włączona w całokształt duszpasterstwa i dlatego przestaje być lekcją przekazywanej wiedzy religijnej, ale staje się formą wychowawczą Kościoła, który poprzez przepowiadanie słowa urzeczywistnia sam siebie. Dzięki katechezie katechizowani rozwijają wiarę otrzymaną na chrzcie, wchodzą w życie Kościoła i przez uczestnictwo w sakramentach, zwłaszcza Eucharystii, pogłębiają w sobie życie dzieci Bożych, które tym sposobem tworzą wspólnotę wiary i miłości ${ }^{5}$. Dlatego każdy prowadzący katechezę winien uświadamiać sobie, jak ważne zadania stoją przed nią, gdyż chodzi przecież o budzenie wiary, umocnienie jej, zbliżenie katechizowanych wychowanków do Boga i wprowadzenie ich do wspólnoty chrześcijańskiej ${ }^{6}$.

Adhortacja Catechesi tradendae stwierdza, że „w Kościele Jezusa Chrystusa nikt nie może uważać się za zwolnionego od obowiązku uczestnictwa w katechezie" (Ctr, nr 45). W dokumencie podkreśla się potrzebę katechezy dla różnych kategorii wiekowych (por. Ctr, nr 36-45), ponieważ dla różnych etapów życia człowieka przybiera ona szczególne właściwości (por. Ctr, nr 35). Catechesi tradendae jako pierwszą grupę katechizowanych wymienia dzieci młodsze (por. Ctr, nr 36). Drugą kategorię wiekową stanowią dzieci starsze (por. Ctr, nr 37). Następnie trzecią grupę katechizowaną stanowią młodzi dorastający, przeżywający czas dojrzewania (por. Ctr, nr 38). Czwartą grupą jest młodzież przeżywająca okres pierwszych wielkich decyzji (por. Ctr, nr 39; 41; 42). I wreszcie ostatnią grupe

${ }^{2}$ H. Wistuba, Wspólnota parafialna, Olsztyn 1993, s. 15.

${ }^{3}$ J. Krucina, Gdzie Kościót jest rzeczywistościa, Wrocław 1993, s. 34.

${ }^{4}$ J. Stroba, W kierunku katechezy integralnej-Synod 1977, w: J. Krucina (red.), Ewangelizacja, Wrocław 1980, s. 46; por. L. Woźniak, Wspótpraca rodziców z katechezq parafialnq, Katecheta 27 (1983), s. 149-152.

${ }^{5} \mathrm{M}$. Majewski, Refleksje teologiczne nad katechezq w świetle dokumentu „Ewangelizacja i sakramenty”, Katecheta 18 (1974), s. 159; por. W. Kubik, Zadania i treści religijnego wychowania małego dziecka, w: W. Kubik (red.), Jezus Chrystus z nami. Podręcznik dla katechizacji dzieci najmłodszych, t. I, Spotkanie z Jezusem we wspólnocie Kościoła, Warszawa 1983, s. 26-27.

${ }^{6}$ W. Kubik, Zarys dydaktyki katechetycznej, Kraków 1990, s. 98-99. 
katechizowanych stanowia dorośli (por. Ctr, nr 43-45). Adhortacja przestrzega, aby katecheza dzieci, młodzieży i dorosłych nie stanowiła oddzielonych od siebie terenów pozbawionych wzajemnych kontaktów ${ }^{7}$. W Catechesi tradendae czytamy o wzajemnych relacjach pomiędzy tymi grupami. Nie może dojść ,między nimi do całkowitego rozłamu, lecz wręcz przeciwnie, trzeba, aby się one między sobą uzupełniały. Dorośli mają wiele do dania młodzieży i dzieciom w dziedzinie katechezy, ale mogą też wiele od nich otrzymać dla wzrostu własnego życia chrześcijańskiego (Ctr, $\mathrm{nr} 45)^{8}$.

Na poszczególnych etapach życia człowieka katecheza nie tylko podejmuje refleksję nad treścią i podstawowymi tematami nauczania kościelnego ${ }^{9}$, ale również ma prowadzić do zawiązania wspólnoty wiary w tych grupach katechetycznych, a także do tworzenia i budowania wspólnoty wiary w rodzinie, parafii, diecezji i w wymiarze Kościoła powszechnego.

Celem katechezy jest realizowanie zadań prowadzących do dojrzałości w wierze i budowania wspólnoty wiary. Pomocą w tym wypadku staje się obraz Kościoła jako communio. Powyższy bowiem obraz szczególny akcent kładzie na wewnętrznych, nadprzyrodzonych więzach łączących wszystkich członków Kościoła, jak również na konieczności relacji interpersonalnych, gdyż oba te czynniki razem przetwarzają społeczność w komunię. Dojrzałość w wierze, jako stały proces, dotyczy przede wszystkim katechezy dorosłych, jednakże ma ona swoje podstawy w katechezie dzieci i młodzieży. Stąd pojawia się konieczność katechezy permanentnej, towarzyszącej wszystkim etapom życia ludzkiego, prowadzącej do dojrzałej wiary i budowania wspólnoty wiary ${ }^{10}$. Zanim jednak dojdzie do powstania takiej wspólnoty, rodzą się grupy, w których uczestnicy dojrzewają do dialogu, poszerzenia światopoglądu, pogłębienia wiary i postawy chrześcijańskiej i wspólnotowej (eklezjalnej). Zdaniem J. Kruciny, można wyliczyć następujące rodzaje tych grup:

1. Zespoły, pielęgnujące najpierw znajomość wzajemną, oczekują porozumienia się w dialogu, otwarcia na coraz szerszą wymianę zdań;

2. Grupy, które przechodzą od słowa do działań zazwyczaj zewnętrznych, plasują się przy świątyni lub na terenie parafii. Skupiają się wokół zadań zewnętrznych, zaopatrzeniowych, charytatywnych itp.;

${ }^{7}$ Por. R. Kamiński, Przynależność do parafii katolickiej, Lublin 1987, s. 50-62; por. także J. Bagrowicz, Katecheza na poszczególne etapy życia człowieka, w: W. Kubik (red.), Katecheza po Soborze Watykańskim II w świetle dokumentów Kościoła, t. I, Warszawa 1985, s. 67-73.

${ }^{8}$ R. Kamiński, dz. cyt., s. 56.

9 „Problem przynależności do parafii w płaszczyźnie wiary ukazuje się wyraźniej w kontekście refleksji nad treścią i podstawowymi tematami nauczania parafialnego. W świetle nauczania kościelnego przepowiadanie słowa Bożego ma się «karmić» Pismem świętym (KL 35; KO 21; 24), i liturgią (KL, nr 35). Podstawą przepowiadania ma być Tradycja, Urząd Nauczycielski i życie Kościoła, a także wartości ludzkie”. Tamże, s. 65.

${ }^{10} \mathrm{~J}$. Charytański, Jakie wspólnoty pobudzajq i podtrzymujq dojrzewanie w wierze, Katecheta 33 (1989), s. 194. 
3. Kręgi dyskusyjne, które dialogowi nadają konkretne treści: zagadnienia wiary, kultury, etyki, rodziny, zawodu, pracy, państwa, wartości chrześcijańskich, ogólnoludzkich;

4. Grupy przechodzące od spraw zewnętrznych do wnętrza, do duchowej intymności, nacechowane chęcią pielęgnacji możliwie intensywnej duchowości chrześcijańskiej. Z introwersji mogą znów, ale już na głębszym podłożu, przechodzić do spraw społecznych: parafialnych, rodzinnych, publicznych ${ }^{11}$.

Aby zaistniało poczucie przynależności do grupy z socjologicznego punktu widzenia potrzebne są cztery elementy, do których należą: 1 . interakcja osób w grupie, 2. akceptacja norm grupy, 3. identyfikacja z grupa, 4. akceptacja jednostki przez grupę ${ }^{12}$.

Interakcja dokonuje się wtedy, gdy osoby spotykają się dla wykonywania wspólnych zadań. Człowiek bez konkretnego zadania traci rację bytu w grupie i zanika u niego poczucie przynależności do niej. Zatem młodzież i dorośli nie widzą swojej roli w Kościele wówczas, gdy nie posiadają wyznaczonych dla siebie konkretnych zadań w parafii.

Akceptacja norm w grupie dokonuje się stopniowo. Jednakże może dokonywać się szybciej w małej grupie, ponieważ ułatwiona jest w niej komunikacja, czyli porozumiewanie się jej członków. Dokonuje się to nie przez samo pouczenie, lecz dzięki częstej ekspresji pewnej postawy.

Identyfikacja z grupą istnieje wówczas, gdy pojedyncza osoba skłonna jest mówić „my”, myśląc o sobie i grupie. Ta identyfikacja dokonuje się łatwiej, gdy członkowie grupy mają jednakowy wiek, religię, narodowość, wspólne poglądy i często się spotykają. Ważne jest również wspólne realizowanie zamierzonych zadań. Osiagnięcie wyznaczonego celu daje satysfakcję i wzmacnia spójność grupy oraz zwiększa jej siłę do realizacji następnych zadań.

Akceptacja jednostki przez grupe posiada znaczenie wtedy, gdy grupa daje odczuć, że jednostkę uznaje za swoją, broni ją i wspiera. Taka świadomość zwiększa się wówczas, gdy członkowie grupy spotykają się ze sobą przede wszystkim osobowo a nie rzeczowo. Spotkanie rzeczowe zachodzi, gdy jego przyczyna jest potrzeba materialna. Natomiast spotkanie osobowe charakteryzuje się tym, że jego przyczyną (celem) jest sama osoba ${ }^{13}$.

Grupa katechetyczna, tak jak każda inna wspólnota wiary, powinna stać się małym Kościołem na wzór Kościoła domowego. Tak jak św. Paweł określał Kościół, pisząc: „Pozdrówcie braci w Laodycei, zarówno Nimfasa, jak i Kościół gromadzący się w jego domu" (Kol 4, 15), w ten sposób katechizowany młody człowiek przyzwyczai się do tego, że jest członkiem Kościoła i równolegle z katechezą szkolną lub po jej ukończeniu będzie szukać uczestnictwa w życiu parafii

\footnotetext{
${ }^{11}$ J. Krucina, Gdzie Kościół..., s. 34-35.

${ }_{12}^{12}$ M. Tomasik, Katechetyka, Sandomierz 1984, s. 46.

${ }^{13}$ Tamże, s. 46-47.
} 
i innych grup religijnych (np. duszpasterstwa akademickiego). Grupy te moga go w jego rozwoju duchowym wspierać ${ }^{14}$.

Czy tego rodzaju poczucie przynależności do wspólnoty może rodzić się na katechezie? Podczas katechezy człowiek powinien wejść w kontakt z osobą Boga, czyli powinien odkrywać Jego tajemnice, Jego obecność, Jego działanie w sobie i innych uczestnikach katechezy. Razem z innymi winien zgłębiać Jego orędzie, nasycać się Jego Prawda, pozwalać przeniknąć się Jego światłu. Dlatego w duchu właściwej dydaktyki i mając na uwadze tworzenie z grupy katechetycznej wspólnoty wiary, katecheza nie może być monologiem, a wykład powinien być w niej sprowadzony do minimum. Katechizowani nie mogą być biernymi słuchaczami. Stąd jawi się potrzeba takich form katechezy, które by prowadziły do rozmowy, wzajemnego dzielenia się wiarą, które by uczyły stawiać pytania, wyrastające, z życia i pozwoliły wspólnie szukać na nie odpowiedzi w Objawieniu wiecznie żywym, we wspólnocie Kościoła. Wprowadzenie dialogu, wzajemnej komunikacji, uczestnictwa staje się pomocą do powstawania i rozwijania wspólnoty wiary pomiędzy katechizowanymi ${ }^{15}$.

Wiedza przekazywana na katechezie nie jest wiedzą o rzeczach, lecz wiedzą o życiu. Tak jak wiedzę o życiu można przekazywać i zdobyć w grupie o wspólnych przekonaniach, tak również wiedzę o życiu wiary można przyjmować i dalej rozwijać poprzez udział w życiu wspólnoty wiary. W katechezie musi dojść do głosu życie wiary wspólnoty, czyli uczenie się wiary jednych od drugich i z drugimi. Wynika stąd potrzeba przekazywania innym świadectwa własnej wiary, dzielenia się nią, aby każdy mógł czerpać siłę ze świadectwa innych. W takiej sytuacji katecheza staje się procesem, w którym wspólnota nie tylko daje, ale także otrzymuje ${ }^{16}$.

Działalność katechetyczna w tworzeniu wspólnoty wiary winna się przejawiać w realizacji funkcji, które sprowadzają się do czterech czynności: budowania wspólnoty, wielbienia, służby i posłannictwa. Te cztery funkcje katechezy posiadają swoje podstawy w misji Jezusa Chrystusa, który kształtował Lud Boży (wspólnota), wielbił Boga, swego Ojca (misja kapłańska), nauczał (misja prorocka) i służył (misja królewska) ${ }^{17}$.

W Kościele jak i w jego różnych wspólnotach dochodzić powinno do przenikania się podmiotowości Chrystusa z podmiotowością Ludu Bożego. Dotyczy to przede wszystkim przenikania się sakramentalnej, a także pasterskiej struktury Kościoła, będącej przedłużeniem oddziaływania Chrystusa z postawami wiernych. W ten sposób rozwija się Kościół, parafia, wspólnoty kościelne, kateche-

${ }^{14}$ M. Braun-Gałkowska, Środowisko wychowawcze: dom, szkoła, grupa rówieśnicza, parafia, w: J. Krucina (red.), Katecheza w szkole, Wrocław 1992, s. 61-62.

${ }^{15}$ Por. W. Kubik, Zarys..., s. 99-100; por. J. Bagrowicz, Katecheza epoki dialogu, AK 104 (1985), s. 249-250.

${ }^{16}$ W. Kubik, Zarys ..., s. 101.

${ }^{17}$ E. Henschke, Katecheza zorientowana na integracje (III), Katecheta 33 (1989), s. 98-99. 
tyczne, czyli rozwój wiary dotyczy owego „my” w Chrystusie, nie „my” jako podmiot wyłączny i ostateczny, tylko „my” w Chrystusie. Chrystus jako podmiot, jako Dobry Pasterz przede wszystkim, a „my” o tyle, o ile uczestniczymy w Jego troistym posłannictwie ${ }^{18}$.

Warto zauważyć, że wyeksponowanie wspólnotowego wymiaru katechezy ma również reperkusje praktyczne, ponieważ katecheza nie może się realizować na marginesie życia parafialnego, gdyż winna być ona zintegrowana z życiem tej wspólnoty ${ }^{19}$. Katecheza bowiem winna przyczyniać się do tego, aby zarówno na płaszczyźnie poznania, jak i w praktyce „wzrastało ziarno wiary, dane przez Ducha Świętego wraz z pierwszym przekazem Ewangelii i w sposób skuteczny udzielone przez chrzest" (Ctr, nr 20). Faktem jest, że adresatami katechezy są poszczególni chrześcijanie, bowiem „katecheza dąży do tego, aby pogłębiać rozumienie Tajemnicy Chrystusa w świetle Słowa, aż cały człowiek będzie nasycony Jego światłem. Przemieniony przez działanie łaski w nowe stworzenie, chrześcijanin zaczyna naśladować Chrystusa i z dnia na dzień uczy się w Kościele coraz lepiej myśleć jak On, oceniać jak On, postępować zgodnie z Jego przykazaniami i ufać, tak jak On nas do tego wzywa" (Ctr, nr 20). Jednakże w istocie rzeczy katecheza jest zadaniem wspólnoty wierzących i poszczególne jednostki prowadzić ma do wspólnoty wiary, wspólnoty Kościoła ${ }^{20}$.

Ten ważny element dotyczący zadań związanych z tworzeniem wspólnoty wiary i Kościoła podkreśla w swojej adhortacji papież Jan Paweł II, stwierdzając, że „katecheza pozostaje wreszcie w ścisłym związku z odpowiedzialną działalnością Kościoła i chrześcijan w świecie. Kto przez wiarę złączył się z Jezusem Chrystusem i stara się umocnić tę wiarę przez katechezę, ten powinien żyć we wspólnocie z tymi, którzy idą tą samą drogą. Grozi bowiem niebezpieczeństwo, że katecheza stanie się bezowocna, jeśli wspólnota wierzących i żyjących w chrześcijaństwie nie przyjmie katechumena - na pewnym etapie nauczania katechetycznego - do swego grona. Wspólnota kościelna, jakiegokolwiek stopnia, ma więc podwójne zadanie do spełnienia w dziedzinie katechezy: zadbać o nauczanie swych członków i przyjąć ich, zapewniając im takie warunki, by mogli żyć jak najpełniej tym, czego się nauczyli” (Ctr, nr 24).

Katecheza może także inspirować do tworzenia innych wspólnot wiary, odrębnych od wspólnot katechetycznych. Istnienie i ciągły rozwój różnego rodzaju wspólnot, w których młodzi ludzie chcą czuć się sobą i wraz z innymi doskonalić siebie i środowisko, posiadają ogromne znaczenie dla rozwoju Kościoła. Do tych grup należą: wspólnoty samokształceniowe, modlitewne, apostolskie, liturgiczne, charytatywne, oazowe, charyzmatyczne itp. Często bywają to grupy nieformalne, powstające w związku z duszpasterską pracą Kościoła lub niezależnie od niej. Działalność takich grup należy oceniać pozytywnie, a ich rozwój pod opieką

\footnotetext{
${ }^{18}$ J. Krucina, Gdzie Kościót..., s. 51.

${ }^{19}$ E. Henschke, dz. cyt., s. 99.

${ }^{20}$ W. Kubik, Zarys ..., s. 98.
} 
Kościoła traktować należy jako zdrowy zaczyn dla rozwoju wspólnot wiary, charakteryzujących się autentyczną religijnością, dawaniem świadectwa wiary i moralnością chrześcijańską ${ }^{21}$. Wspólnoty takie powstają i rozwijają się dokoła trzech formujących je i warunkujących ich spoistość czynników: 1. autentyczne życie z Bogiem poszczególnych członków; 2. pogłębianie wiedzy religijnej w ustalonym zakresie i formie - jako wewnętrzne zadanie wspólnoty; 3. podejmowanie wspólnych lub indywidualnych zadań apostolskich - jako zadanie zewnętrzne wspólnoty $^{22}$. Świadectwo tychże wspólnot polega na życiu zgodnym z wyznawaną wiarą. Życie chrześcijańskie bowiem musi wykazać się uczynkami sprawiedliwości i miłości ${ }^{23}$. W Dyrektorium Katechetycznym czytamy, że „,najlepszym sposobem, w jaki wierni mogą dopomóc zateizowanemu światu dojść do Boga jest świadectwo ich życia zgodnego z orędziem miłości Chrystusowej oraz żywej i dojrzałej wiary, która ujawnia się w uczynkach sprawiedliwości i miłości (por. KDK, nr 21)" (DCG, nr 49) $)^{24}$.

Aby dotrzeć do wszystkich poszukiwań, potrzeb, doświadczeń ludzkich, nie wystarczy dobrze przygotować katechezę od strony intelektualnej na sposób konferencji. Do ważnych spraw należy dopuszczenie do głosu uczestników katechezy. Ujawnione przez nich warunki i problemy winny wyznaczać konkretne cele działania katechetycznego. Dlatego też forma poszukująca staje się bardziej odpowiednia od wykładowej, ponieważ katechizowani z biernych odbiorców stają się aktywnymi poszukiwaczami rozwiązań w świetle Ewangelii ${ }^{25}$ i mogą budować wspólnotę wiary.

Taką wspólnotę winna cechować modlitwa, pogłębianie życia z Bogiem, aby potem w swoim życiu osobistym i w swoim środowisku lepiej prezentować swoją wiarę, lepiej pracować. To niewątpliwie wpływa na odradzanie się Kościoła od wewnątrz, a także inspiruje do podejmowania wspólnych zadań apostolskich ${ }^{26}$.

Koncepcja formy małych wspólnot wynika z potrzeby przygotowania ludzi świeckich do odpowiedzialności za Kościół, z natury rzeczy wymaga więc dużej inicjatywy z ich strony i zaangażowania. Każda autentyczna wspólnota wiary formułuje własne poglądy, sposoby działania, natrafia również na swoiste dla niej trudności. Do zadań duszpasterza, katechety, przewodnika grupy należy wyjaśnianie, korygowanie i pomaganie, ale zawsze istotne jest dopuszczanie do głosu inicjatyw członków wspólnoty, aby one zaowocowały w życiu codziennym. Tą drogą prowadzi się katechizowanych do podejmowania odpowiedzialności

${ }^{21}$ Z. Pawłowicz, Stanowisko wspótczesnych synodów europejskich wobec problemu młodzie$\dot{z} y$, Katecheta 29 (1985), s. 20.

${ }^{22}$ H. Wistuba, Praca z małymi wspólnotami w parafii, Katecheta 26 (1982), s. 217.

${ }^{23}$ M. Tomasik, dz. cyt., s. 45.

${ }^{24}$ Tamże, s. 45.

${ }^{25}$ J. Charytański, Parafia wspólnota przekazu wiary i życia chrześsijańskiego, w: J. Krucina (red.), Ewangelizacja..., s. 219-220.

${ }^{26}$ H. Wistuba, Praca ..., s. 215-216. 
za ich obecność w środowisku, za świadectwo wiary i odpowiedzialności za Kościół ${ }^{27}$.

Tak więc dostrzegamy, że katecheza nie tylko przekazuje treści wiary na zasadzie informacji i podania programowej ilości materiału i wiedzy religijnej, lecz winna wypełniać zadania formacyjne katechizowanych. Stąd utworzenie z grupy katechetycznej wspólnoty wiary winno być jej zasadniczym celem. Taka wspólnota wiary bowiem wprowadza w dojrzałość chrześcijańską i w życie Kościoła, stając się w ten sposób małym Kościołem, czyli wspólnotą eklezjalną.

\section{Ksztaltowanie nowej świadomości o Kościele}

Konstytucja duszpasterska o Kościele w świecie współczesnym ukazuje kierunki zmian, zachodzących w świecie. Wielkie zmiany, a więc rozwój i postęp oraz dążenia do jednoczenia się ludzkości, mają wpływ na przebudowę świadomości człowieka. Dzięki tym zmianom Kościół na nowo przeżywa swoją istotę i swoją misję $e^{28}$. Jak to już wskazaliśmy w tej pracy, Sobór Watykański II pod wpływem współczesnych warunków życia i rozwoju teologii przeprowadził analizę istoty Kościoła. Zwłaszcza z Konstytucji Lumen gentium wynika, że Kościół w swej najgłębszej istocie jest tajemnicą, złożoną rzeczywistością porządku nadprzyrodzonego, której nie można poznać tylko naturalnym rozumem, pomijając objawienie i wiarę. Tajemnice Kościoła wyraża się we wspólnocie ludzi zjednoczonych przez wiarę i miłość z Chrystusem. Kościoła nie można widzieć i rozumieć tylko w aspekcie instytucjonalnym, zmierzającym do wychowania człowieka szlachetnego, ale również należy zwrócić uwagę na ten aspekt Kościoła, który daje człowiekowi nowe życie, nadprzyrodzoną pozycję i który wspiera go w drodze do nadprzyrodzonych przeznaczeń ${ }^{29}$.

Dzięki dorobkowi Soboru i rozwijającej się eklezjologii rozwinęła się nowa świadomość Kościoła o sobie ${ }^{30}$. Świadomość Kościoła potrydenckiego i z okresu Soboru Watykańskiego I oraz utrwalone wtedy struktury już nie wystarczają do określenia istoty i do wypełniania jego misji w ciagle zmieniającym się świecie. Kościół opierający się jedynie na stanie duchownym, wyobcowywał się ze współczesności, zamykał się w swego rodzaju getcie. Stąd bellarminowska definicja Kościoła obecna w nauczaniu religijnym została częściowo zastapiona, a częściowo ubogacona nowymi elementami ${ }^{31}$.

27 Tamże, s. 218.

${ }^{28}$ Por. J. Charytański, Zadania katechizacji w świetle dokumentów soborowych, w: $W$ kręgu zadań i treści katechezy, Kraków 1992, s. 11-12.

${ }^{29}$ H. Łuczak, Wspólnota wiary, Wrocław 1986, s. 182.

${ }^{30}$ Por. J. Bagrowicz, Odnowa Kościoła jako warunek skuteczności katechezy, AK 102 (1984), s. $382-383$.

${ }^{31}$ Por. J. Charytański, Zadania katechizacji..., s. 12-13. 
Epoka Soboru i teologia posoborowa sprawiły, że katecheza odeszła od bellarminowskiej definicji Kościoła i przyswoiła sobie całe bogactwo współczesnej eklezjologii. Jest oczywiste, że katecheza winna uwypuklać tajemnicę Kościoła. Chodzi przede wszystkim o przedstawianie Kościoła na tle historii zbawienia, opartej na Piśmie świętym. Punktem wyjścia będzie nie tyle abstrakcyjna definicja katechizmowa, co idee (Ludu Bożego, Przymierza, Królestwa Bożego, Ciała Chrystusowego) i obrazy Kościoła (winnica, owczarnia, budowla, świątynia, niebieskie Jeruzalem, Oblubienica Chrystusa), ukazujące całą rzeczywistość Kościoła. Ponadto należy przedstawić Chrystusa uwielbionego w sakramentach, które objawiają i urzeczywistniają Kościół. Katecheza o Kościele nie może o czym już niejednokrotnie wspominano - ograniczać się w całokształcie programu katechetycznego do kilku lekcji, czy specjalnych jednostek lekcyjnych, lecz cała katecheza winna prowadzić do Kościoła, aby w jego tajemnicy dokonała się synteza całościowej wizji chrześcijaństwa ${ }^{32}$.

Kościół w rzeczywistości musi stawać się wspólnotą wiary, nadziei i miłości (por. KK, nr 8). Nie może być zamkniętą grupą uprzywilejowanych, lecz wspólnotą otwartą i dialogalna, która buduje wraz z innymi ludźmi nowa, wciąż udoskonalaną społeczność. Relacje wewnątrzkościelne, zwłaszcza autorytetu i sprawowania władzy, winny ulec zmianie. Styl władczy oraz infantylizujący, inspirowany przez modele społeczne przeszłości, musi zostać zastapiony stylem ewangelicznym w duchu Soboru Watykańskiego II $^{33}$.

Źródłami życia Kościoła jest Pismo Święte i liturgia ${ }^{34}$. Jak już powiedziano, Biblia ukazuje tajemnicę Kościoła za pomocą różnych obrazów wziętych z codziennego życia, by na drodze podobieństwa przybliżyć różne aspekty owego misterium. Dotyczy to odsłonięcia głębi tych obrazów, mających teologiczne i duchowe znaczenie w życiu wierzących. I tak analizują i komentują owe teksty biblijne Ojcowie soborowi ${ }^{35}$. Konstytucja o liturgii podkreśla misterium Chrystusa, tajemnicę naszego odkupienia, w której urzeczywistnia się zamysł Boga zbawienia wszystkich ludzi i dojścia do poznania prawdy (por. $1 \mathrm{Tm}$ 2, 4; KL, nr 5). Działająca stale tajemnica Chrystusa jest wciąż obecna jako widzialny sakrament zbawczej jedności dla wszystkich razem i dla każdego z osobna. Ukonkretnieniem tej tajemnicy jest Kościół, który jest Królestwem Bożym w tajemnicy (por. KK 1$)^{36}$. Tajemnica eucharystyczna jest prawdziwie ośrodkiem liturgii oraz całego życia chrześcijańskiego. Stąd Kościół pouczony przez Ducha Świętego usiłuje coraz bardziej ją zgłębiać i coraz intensywniej z niej żyćc ć $^{37}$. Kościół jest ludem

${ }^{32}$ S. Bradtke, Posoborowa koncepcja pedagogiki katechetycznej apostolstwa misyjnego, Katecheta 20 (1976), s. 4-5.

${ }^{33}$ H. Pagiewski, Katechizm na nasze czasy, Katecheta 21 (1977), s. 5.

${ }^{34}$ J. Stroba, Synod Nadzwyczajny..., s. 99.

${ }_{35}$ B. Mokrzycki, Misterium Kościoła, Warszawa 1987, s. 17.

${ }^{36}$ B. Nadolski, Urzeczywistnianie się Kościoła w liturgii w świetle dokumentów Vaticanum II, Poznań 1981, s. 15.

${ }^{37}$ B. Mokrzycki, dz. cyt., s. 102. 
zjednoczonym, jednością Ojca i Syna i Ducha Świętego (por. KK, nr 4). Ta właśnie jedność najpełniej dokonuje się i uprzytamnia w sprawowaniu Eucharystii $(\mathrm{KK}, \mathrm{nr} 3)^{38}$.

Kościół narodził się z ofiary Chrystusa, dzięki Misterium Paschalnemu stał się Ludem Nowego Przymierza. Bóg obdarowuje swój lud miłością, a zarazem wzywa do wierności. Katechezie przypada szczególna rola budzenia i kształtowania świadomości udziału w kapłaństwie wspólnym, a więc współodpowiedzialności za Kościół i jego wzrost w Panu. Jednakże wynik zależy od tego, czy katecheza jest „szkołą”, grupą dyskusyjna, czy też „małym Kościołem” skupionym wokół Chrystusa ${ }^{39}$.

Kościół nie jest tylko środkiem do osiagnięcia zbawienia, lecz jest samym zbawieniem widzialnie realizowanym na tym świecie przez zmartwychwstałego Chrystusa. W Kościele Chrystus dalej oddziałuje na ludzi jako Zbawiciel świata, a ponadto w Kościele ma swój zalążek Królestwo Niebieskie czy też Królestwo Boże na ziemi. Jest to królestwo prawdy i życia, świętości i łaski, sprawiedliwości, miłości i pokoju. Stąd Kościół jest przedłużeniem Chrystusa w czasie i przestrzeni ${ }^{40}$. Kościół jest zaczynem, fermentem, małym ziarnkiem, małą grupa, przez którą Bóg chce zbawić wielu. Działalność samego Chrystusa nie przedstawiała się zbyt efektywnie z punktu widzenia ilościowego. Kościół nie jest nad swego Mistrza Jezusa Chrystusa. Jednakże dzieło Jezusa od strony jakościowej jest niezmierzone, ponieważ dotyczy zbawienia wszystkich ludzi. Zatem nie można kierować się tylko sposobem myślenia ilościowym, arytmetycznym, gdzie liczy się liczba i siła presji wywieranej na innych. Wszyscy są równi wobec realności zbawienia (por. KDK, nr 22). Istnieje jedna tajemnica zbawienia dla wszystkich w Jezusie Chrystusie, lecz jedni są świadomi tego, i to są chrześcijanie, inni natomiast nie posiadają tej świadomości ${ }^{41}$.

Jak zauważamy, Kościół w świecie współczesnym żyje w rzeczywistości, która podlega nieustannym przemianom. Ta zmieniająca się rzeczywistość wymaga szczególnej refleksji i pogłębionej samoświadomości Kościoła. Dlatego katecheza będąc elementarnym i systematycznym nauczaniem prawd wiary, czy bardziej procesem przekazywania i przyjmowania wiary, jest również procesem rozwoju samoświadomości Kościoła ${ }^{42}$. Dlatego w kształtowaniu świadomości o Kościele należy uwypuklić jego element boski i ludzki, niewidzialny i widzialny. Stanowi on bowiem dostrzegalne zrzeszenie, które ma swoje organy hierarchiczne i równocześnie jest niewidzialną wspólnotą duchową w Chrystusie, wspólnotą wiary, nadziei i miłości ${ }^{43}$.

${ }^{38}$ J. Charytański, Skupić się na istotnym. Wprowadzenie teologiczne, w: J. Charytański, Kościót wspólnotq eucharystycznq. Podręcznik dla katechezy, Warszawa 1974, s. 9.

${ }^{39}$ Tenże, Z Dobra Nowinq w szkole, Warszawa 1991, s. 76.

${ }^{40}$ H. Łuczak, dz. cyt., s. 182.

${ }^{41}$ H. Pagiewski, dz. cyt., s. 5.

${ }^{42}$ Por. G. Kusz, Katecheza i jej miejsce w Kościele (I), Katecheta 26 (1982), s. 10-11.

${ }^{43}$ H. Luczak, dz. cyt., s. 182. 
Zgodnie z zasadą korelacji, Kościół winien być rozpatrywany nie tyko w sobie, ale w odniesieniu do kultury, jak również do poszukiwania sensu. Istnieje bowiem ścisły związek między indywidualnym, a kolektywnym jego poszukiwaniem. Takie podejście i rozumienie Kościoła wiąże się z doświadczeniem religijnym. Kiedy człowiek w swoje doświadczenie religijne włącza również doświadczenie innych, otwiera się droga doświadczenia Kościoła, jako doświadczenia Boga $^{44}$.

Kościół jest specjalnym miejscem dla wszystkich chrześcijan, w którym można doświadczyć bliskości Boga i Jego zbawienia. Jest on sakramentem jedności ludzi z Bogiem i pomiędzy sobą, to znaczy jest znakiem przyszłego świata, znakiem, w którym to, co przyszłe, jest już obecne. Ta wielka rzeczywistość znaku zbawienia może się stać jasna i widoczna dla świata tylko poprzez życie wierzących zgodne z Ewangelią. Może się więc objawić w działaniu Kościoła jako społeczności chrześcijan żyjących w jedności z Bogiem i pomiędzy sobą oraz wyznających swoją wiarę w sakramentach świętych, a zwłaszcza w chrzcie świętym i w Eucharystii ${ }^{45}$. I tu specjalną rolę może spełnić katecheza. W całym procesie katechetycznym chrześcijanin winien zebrać doświadczenie wewnętrzne zarówno rzeczywistości Kościoła, jak również swojej własnej w nim roli. Dlatego najpierw problem ten dotyczy doświadczenia prawdziwej wspólnoty kościelnej w grupie katechetycznej. Następnie nieodzownym jest doświadczenie wspólnoty prawdziwie ludzkiej w odniesieniu do parafii czy diecezji. Niezbędnym jest pełnienie ról rzeczywistych we wspólnocie Kościoła, a nie tylko mówienie o nich ${ }^{46}$. Inaczej mówiąc, zadaniem katechezy jest kształtowanie wizji Kościoła dynamicznego, eschatologicznego, Kościoła jako źródła rozwijających i ubogacających wartości ${ }^{47}$.

Biorąc pod uwagę wizję Kościoła dynamicznego, należy podkreślić znaczenie misji słowa w Kościele. W tym kontekście pojawia się zagadnienie inkulturacji oraz ewangelizacji kultur przy przyjęciu powszechności owej misji. Przekaz objawienia ujmowany jest w jego wymiarze dynamicznym, to jest podkreślane coraz głębsze zrozumienie, wyznawanie i głoszenie dzięki konfrontacji ze zmieniającymi się sytuacjami człowieka, jednak zawsze pod kierunkiem Nauczycielskiego Urzędu Kościoła. Dlatego konieczne jest podczas katechezy omawiać rolę Pisma Świętego w życiu chrześcijanina jako źródła światła i wezwania w roz-

44 „Przeżywa się swoje doświadczenie jako cząstka większej całości, a zarazem uznanie własnej fragmentaryczności otwiera na doświadczenie całej rzeczywistości. Decydującym jest owo przeżycie «my». Poszukiwanie sensu przez jednostkę dokonuje się w konfrontacji poszukiwania sensu przez Kościół lokalny i powszechny”, Por. J. Charytański, Program katechezy na poziomie licealnym w zmienionej sytuacji ekonomiczno-społecznej, w: J. Krucina (red.), Katecheza w szkole..., s. 85 .

${ }^{45}$ W. Kubik, ,Zarys wiary” - nowy katechizm, Katecheta 30 (1989), s. 69.

${ }^{46}$ J. Charytański, Chrystus w przepowiadaniu katechetycznym, w: J. Charytański i W. Kubik (red.), Podręcznik metodyczny do Katechizmu Religii Katolickiej, t. II, Warszawa 1978, s. 13.

${ }^{47}$ J. Szarkowski, Odpowiedzialność za Kościót? Ale jaki?, Katecheta 20 (1976), s. 122. 
wiązywaniu problemów ludzkich, indywidualnych i społecznych ${ }^{48}$. Zasadniczo młodzież posiada już doświadczenie życia społecznego, młodzi znają wiele grup odniesienia i ich strukturę. W odniesieniu do tych grup katecheza powinna przybliżać przede wszystkim tajemnicę Kościoła jako rzeczywistości bosko-ludzkiej, w której jest obecny i działa Chrystus mocą Ducha Świętego. Kościół pozostaje w służbie Królestwa Bożego. Dopiero po ukazaniu tego aspektu służby zadaniem katechezy jest przedstawienie struktury hierarchicznej Kościoła, a także roli laikatu czy wreszcie zakonów. Kościół winien więc ukazać się katechizowanym jako wspólnota-komunia w służbie ludzkości. Możemy również mówić młodym o proegzystencji Kościoła. Przy takim ujęciu Kościoła podczas katechezy kształtowane są postawy allocentryczne oraz postawy otwarcia się na drugich, jako warunku poszukiwania sensu ${ }^{49}$.

Reasumując trzeba podkreślić, że katecheza powinna kształtować nową świadomość o Kościele. Zwłaszcza, że ciagle zmieniająca się sytuacja w świecie inspiruje do zrozumienia pełnej rzeczywistości Kościoła, aby jej członkowie jak najlepiej i dogłębnie ją poznawali. Ta nowa świadomość o Kościele stanie się pierwszym krokiem do odnalezienia przez Kościół właściwego miejsca w świecie. Ponadto, aby Kościół posiadał siłę wyzwalająca, musi ciągle zgłębiać swoją tajemnicę, by w rzeczywistości stać się wspólnotą wiary, nadziei i miłości ${ }^{50}$.

Należy zaznaczyć, że zadanie kształtowania nowej świadomości o Kościele jest realizowane w niektórych współczesnych materiałach i podręcznikach katechetycznych. Omawianie tego problemu przekracza jednak zakres tej pracy.

\section{Wychowanie świadomości poczucia przynależności do Kościoła}

Wynikiem samouświadomienia Kościoła na Soborze jest sformułowanie najbardziej fundamentalnego pojęcia dla życia Kościoła, a mianowicie określenie Kościoła jako powszechnego sakramentu zbawienia. Konsekwencje z przyjęcia takiego pojęcia dotyczą zarówno życia wewnątrzkościelnego, jak i działalności Kościoła w relacji do świata. W jednym i drugim przypadku dowartościowano laikat, określając jego miejsce i rolę, jaką powinien wypełniać tak w Kościele, jak i w świecie ${ }^{51}$.

Podejmując problematykę przynależności do Kościoła, katecheza nie powinna pomijać znaczenia i skutków, jakie niesie przyjęty przez człowieka sakrament chrztu. Człowiek przez przyjęcie sakramentu chrztu staje się dzieckiem

${ }^{48}$ J. Charytański, Program katechezy..., s. 86.

${ }^{49}$ Tamże, s. 86.

${ }^{50}$ H. Pagiewski, dz. cyt., s. 5.

${ }^{51}$ Por. S. Nagy, Świeccy w komunijnej wspólnocie Kościoła, AK 114 (1990), s. 377-387; B. Dembowski, Rola Kościoła w epoce przemian (1978-1991), AK 119 (1992), s. 93-94; S. Bradtke, dz. cyt., s. 3. 
Bożym, Jego synem wybranym (por. Ga 4, 4-7) i jednocześnie bratem Chrystusa. W chrzcie „Z wody i Ducha” (J 3, 5) właśnie tenże „Duch Święty nadaje ochrzczonym status synów Bożych, a zarazem czyni ich członkami Chrystusowego Ciała" (ChL, nr 11). Dlatego też do wszystkich świeckich ochrzczonych odnoszą się słowa św. Pawła: „Wy przeto jesteście Ciałem Chrystusa i poszczególnymi członkami” (1 Kor 12, 27), „Wy wszyscy, którzy zostaliście ochrzczeni w Chrystusie, przyoblekliście się w Chrystusa” (Ga 3, 27) i „Wszyscy razem tworzymy jedno ciało w Chrystusie" (Rz 12, 5). Ponadto wszyscy świeccy jako ochrzczeni są jakby „żywymi kamieniami”, które na fundamencie Chrystusa, owym „kamieniu węgielnym”, tworzą i stanowią „duchową świątynię” (1 P 2, 5), „,dom duchowy” (por. KK, nr 10). Sprawia to Duch Święty, który „namaszcza" ochrzczonego, wyciska na nim swoją niezatartą pieczęć (por. 2 Kor 1, 21) i napełnia „świętą obecnością Boga” (ChL, nr 13). Dzięki temu chrześcijanin duchowny czy świecki - może na swój sposób powtórzyć słowa Jezusa: „Duch Pański spoczywa na mnie, ponieważ mnie namaścił i posłał mnie, abym ubogim niósł Dobrą Nowinę" $(Ł k 4,18)^{52}$.

Do podstawowych zadań całego Kościoła należy wychowywanie nowych pokoleń. Wychowanie w swojej istocie nie jest niczym innym, jak kształtowaniem człowieka $i$ to nie w sensie jego rozwoju jako gatunku, lecz w znaczeniu doskonalenia każdego indywidualnego człowieka we wszystkich dziedzinach jego życia i działalności, czyli kształtowaniem osoby ludzkiej. Dotyczy to kształtowania osoby ludzkiej w kierunku jej celu ostatecznego, a równocześnie dla dobra społeczeństwa i Kościoła przez harmonijny rozwój wrodzonych właściwości fizycznych, moralnych i intelektualnych (por. DWCH, nr 1;3) ${ }^{53}$.

W nauczaniu Papieża Jana Pawła II często powraca myśl o tym, że człowiek ma przede wszystkim dążyć do tego, aby „być”, a nie zabiegać wyłącznie o to, aby „mieć”. Taki sposób myślenia i wartościowania stanowi podstawę wychowania opartego na chrześcijańskich zasadach. Ideałem, do którego należy dążyć, jest ukształtowanie człowieka na wzór Chrystusa (por. Ef 4, 20-24). Działania wychowawcze winny przeto zmierzać do wszechstronnego rozwoju wychowanka, dlatego jawi się potrzeba integrowania wszystkich oddziaływań wychowawczych. Chodzi o to, by każde z tych oddziaływań było organizowane pod kątem potrzeb związanych z rozwojem całej osobowości wychowanka, a także by zostały uwzględnione wszystkie sytuacje wychowawcze oraz cel, do którego proces rozwojowy i działania wychowawcze zmierzają. Postulat wszechstronnego oddziaływania wychowawczego na osobę ludzką łączy się z dostrzeżeniem niezmiernie ważnego elementu w dziedzinie wychowania. Oznacza to, że nie można ograniczać wychowania wyłącznie do „cielesności” człowieka, zważywszy

${ }^{52}$ A. Lewek, Nowa ewangelizacja w duchu Soboru Watykańskiego II, t. II, Katowice 1995, s. 339 .

${ }^{53}$ J. Majka, Wychowanie chrześcijańskie - wychowaniem personalistycznym, ChŚ 42-43 (1976), s. 51. 
na jego strukturę cielesno-duchową. Stąd pod określeniem wszechstronnego, pełnego rozwoju i kształtowania osobowości należy rozumieć także formację duchową i religijną człowieka, a oddziaływanie wychowawcze skierować na wszystkie władze duszy, czyli na jego rozum, uczucia i wolę, na całą osobowość człowieka $^{54}$.

Wychowanie chrześcijanina jest wprowadzeniem do życia w społeczności. Tą podstawową społecznością i wspólnotą, w którą katecheza ma wprowadzić, jest Kościół. Wychowanie do życia w Kościele to najpierw kształtowanie świadomości przynależności do Kościoła.

W wychowaniu świadomości przynależności do Kościoła ważną rolę odgrywa kształtowanie postaw eklezjalnych. Decydujące znaczenie posiada tu rozwój religijny człowieka w poszczególnych etapach jego życia, środowisko, do którego należy, a więc rodzina, grupy rówieśnicze, szkoła i Kościół. Od ukształtowania życia religijnego zależy kształtowanie postawy eklezjalnej, od której z kolei zależy świadomość przynależności człowieka do wspólnoty Kościoła ${ }^{55}$.

Na przebieg procesu wychowania religijnego ogromny wpływ wywiera środowisko, w jakim człowiek wzrasta. Do kręgu osób tworzących środowisko zalicza się przede wszystkim rodziców ${ }^{56}$. Rodzina, w której powstaje życie, jest również powołana do wychowawczej troski, czyli staje się podmiotem zobowiązań wychowawczych ${ }^{57}$. Dlatego pierwszym i podstawowym środowiskiem, w którym kształtowane są postawy religijne i eklezjalne, jest rodzina chrześcijańska ${ }^{58}$. W Deklaracji o wychowaniu chrześcijańskim czytamy, że „do rodziców [...] należy stworzyć taką atmosferę rodzinna, przepojoną miłością i szacunkiem dla Boga i ludzi, aby sprzyjała całemu osobistemu i społecznemu wychowaniu dzieci. Dlatego rodzina jest pierwszą szkołą cnót społecznych, potrzebnych wszelkim społecznościom. Szczególnie zaś w rodzinie chrześcijańskiej, ubogaconej łaską i obowiązkami sakramentu małżeństwa, należy już od najwcześniejszego wieku uczyć dzieci zgodnie z wiarą na chrzcie otrzymaną poznawania i czci Boga, a także miłowania bliźniego; tam też doświadczają one najpierw zdrowej społeczności ludzkiej i Kościoła; a wreszcie przez rodzinę wprowadza się je powoli do obywatelskiej wspólnoty ludzkiej i do ludu Bożego. Niech więc rodzice uprzytomnią sobie dobrze, jak wielkie znaczenie ma rodzina prawdziwie chrześcijańska dla życia i rozwoju samego ludu Bożego" (DWCH, nr 3).

Rodzina chrześcijańska jest nie tylko wspólnotą miłości, ale małym domowym Kościołem. W rodzinie i poprzez rodzinę Chrystus realizuje swoje dzieło zbawcze. Rodzina chrześcijańska jako wspólnota uczestniczy w potrójnej misji

${ }^{54}$ Por. Z. Marek, Wychowanie religijne i rozwój człowieka, w: Z. Marek. (red.), W służbie człowiekowi, Kraków 1991, s. 79-80.

${ }^{55}$ A. Paszek, Postawy eklezjalne młodzieży z salezjańskich szkół średnich, (mps KUL), Lublin 1994, s. 20.

${ }^{56}$ Z. Marek, art. cyt., s. 83.

${ }^{57}$ J. Majka, art. cyt., s. 64-65.

${ }^{58}$ A. Paszek, dz. cyt., s. 27. 
Chrystusa: proroczej, kapłańskiej i pastersko-królewskiej. Dziecko ochrzczone od najwcześniejszych lat w rodzinie i wraz z rodziną winno się wdrażać w realizację tej potrójnej misji ${ }^{59}$. W idei małego, ale autentycznego Kościoła wyraża się istota chrześcijańskiej koncepcji małżeństwa, rodziny i kształtowania w niej pełnych ludzi, czyli nowego człowieka. Kościół winien przejąć się kształtowaniem nowego człowieka i konfrontować z nim przyjęty chrześcijański model swego istnienia, a rodziny chrześcijańskie jako małe Kościoły, aby podążały tą samą drogą. Na tym polega eklezjalny wymiar życia rodzinnego. Ponadto istnieje potrzeba wyrastająca $\mathrm{z}$ wiary chrześcijańskiej, aby ten wymiar życia rodzinnego wydatniej zgłębić. Należy więc rodzinę rozważać na podstawie idei Kościoła, zawartej głównie w Konstytucji dogmatycznej o Kościele (por. KK, nr 41), i tą drogą uwyraźnić pełny sens communionis personarum, chrześcijańskiego i eklezjalnego miejsca kształtowania człowieka ${ }^{60}$.

$\mathrm{Na}$ różnych etapach życia rodzinnego poczucie odpowiedzialności za głoszenie prawdy Bożej zawsze jednak musi przekraczać wąski kragg wspólnoty rodzinnej przez zaangażowanie, choćby w formie samej modlitwy, w sprawę katechizacji parafialnej, czy posłannictwa misyjnego Kościoła. Dzieci na wszystkich etapach swojego rozwoju łatwo dają się wciagnąć w tę troskę, ale nieodzowna jest do tego zarówno pewna doza bieżących informacji z życia Kościoła, jak i wskazanie konkretnych form zaangażowania np. modlitwy ${ }^{61}$. W Chrystusie narodziliśmy się jako nowi ludzie, nie tylko w sensie pojedynczo wziętych jednostek, ale jednocześnie i koniecznie jako Ecclesia. To właśnie rodzina, jako Kościół domowy, jest cząstką Kościoła, zjednoczonego Ludu Boga. W ten sposób Kościół wyprzedza ja, ale zarazem rodzina staje się modelem dla całego Kościoła jako wspólnoty. Jednakże nade wszystko w rodzinie powstaje i kształtuje się nowy człowiek, to znaczy, że w niej i przez nią wzrasta cały Kościół. Rodzinę wybrał Bóg jako miejsce realizowania swych planów, czyli obdarowania człowieka uczestnictwem w Bożym życiu, co dopiero daje człowiekowi pełnię istnienia. Rodzina jest więc owym miejscem dla życia w pełni ludzkiego, bo mającego udział w życiu Boga ${ }^{62}$. Dlatego istnieje konieczność porozumienia się i współpracy z Kościołem i Kościoła z domem rodzinnym w wielkim dziele wychowania religijnego i kształtowania chrześcijańskich charakterów. Rodzina winna czuć obowiązek współpracy z Kościołem, ażeby wprowadzać w głębsze zrozumienie wychowania religijnego $\mathrm{w}$ domu. $\mathrm{W}$ tym celu należy podkreślić bezwzględną konieczność stworzenia religijnej atmosfery w rodzinie, która sprzyjałaby rozkwitowi życia religijnego i kształtowania chrześcijańskiego charakteru, a w kon-

${ }^{59} \mathrm{~S}$. Smoleński, Wychowanie w rodzinie jako przygotowanie do odpowiedzialnego podjęcia powołania chrześcijańskiego, w: F. Adamski (red.), Wychowanie w rodzinie chrześcijańskiej, Kraków 1982, s. 80.

${ }^{60}$ T. Sikorski, Rodzina jako źródto ksztaltowania człowieka, ChŚ 94 (1980), s. 27.

${ }^{61}$ S. Smoleński, dz. cyt., s. 81.

${ }^{62}$ T. Sikorski, dz. cyt., s. 28. 
sekwencji prowadziła do ukształtowania postaw eklezjalnych. Tę atmosferę religijną dziecko musi posiadać od najmłodszych lat, nią oddychać, przyswajać ją sobie i wzrastać w nią ${ }^{63}$.

Zagadnienie apostolstwa rodziny staje się więcej niż kiedykolwiek aktualnym zadaniem i nakazem naszych czasów. W świecie, w którym uwidocznia się proces laicyzacji i sekularyzacji, rodzi się obowiązek podjęcia troski o rodzinę. Jest więc rodzina, jako „mały Kościół”, podstawowym i pierwszym środowiskiem budowania świadomości przynależności do Kościoła ${ }^{64}$.

W wychowaniu świadomości przynależności do Kościoła fundamentalne znaczenie posiada społeczność, jaką jest sam Kościół ${ }^{65}$. Deklaracja o wychowaniu chrześcijańskim mówi obowiązku wychowawczym w odniesieniu do Kościoła jako instytucji. Czytamy w Deklaracji, że „w szczególny [...] sposób obowiązek wychowawczy należy do Kościoła nie tyko dlatego, że winno się go uznać za społeczność ludzką zdolną do pełnienia funkcji wychowawczej, lecz nade wszystko dlatego, że ma on zadanie wskazywania wszystkim ludziom drogi zbawienia, a wierzącym udzielania życia Chrystusowego i wspomagania ich ustawiczną opieką, aby mogli osiągnąć pełnię tego życia. Tym więc swoim dzieciom obowiązany jest Kościół jako Matka dawać takie wychowanie, dzięki któremu całe ich życie byłoby przepojone duchem Chrystusowym, równocześnie zaś udzielać swej pomocy wszystkim ludziom do zdobywania pełnej doskonałości ludzkiej osoby, do dobra również ziemskiej społeczności i w budowaniu świata bardziej ludzkiego" (DWCH, nr 3). Tę wychowawczą misję pełni Kościół także przez katechezę.

Zadania wychowawcze katechezy winny dotyczyć także rozwinięcia i pogłębienia poczucia przynależności do Kościoła. Odpowiedzialność za Kościół jest bowiem wynikiem powstania dojrzałej łączności ze wspólnotą kościelną. Nie może być mowy o odpowiedzialności za Kościół, jeśli nie zostało rozwinięte i odpowiednio pogłębione poczucie przynależności do Kościoła ${ }^{66}$. Można spotkać u katechizowanych przynależność do Kościoła, ale raczej na zasadzie przynależności socjologicznej i tradycyjnej jako dziedzictwo po rodzicach katolickich. Aby katechizowani przeżywali wiarę w sposób osobisty, z własnego wyboru, należy u wychowanków pielęgnować i pogłębiać osobową więź z Chrystusem oraz ukazywać wizję Kościoła Chrystusowego jako bogate źródło najgłębszych wartości, które rozwijają i ubogacają człowieka i ludzkość, która ma być dźwignięta wzwyż jako Boża tajemnica w Chrystusowym Kościele, gdyż człowiek i wszechświat jest stworzony w Chrystusie, w Nim żyje i wzrasta, rozwija się i ulepsza ${ }^{67}$.

${ }^{63}$ Por. M. Finke, Pedagogika wiary, Poznań 1996, s. 108-109.

${ }^{64}$ Tamże, s. 111.

${ }^{65}$ Por. J. Słomińska, Świadomość przynależności do grup religijnych u młodzieży biorqcej udziat w katechizacji, Katecheta 19 (1975), s. 246-249.

${ }^{66} \mathrm{R}$. Murawski, Co daje katecheta młodzieży w wychowaniu do odpowiedzialności za Kościót, cz. II, Katecheta 19 (1975), s. 250.

${ }^{67}$ J. Szarkowski, dz. cyt., s. 121. 
Dlatego grupę katechetyczną należy przekształcać w małą wspólnotę kościelną ${ }^{68}$, gdyż pozostawienie katechizowanych przy wierze socjologicznej i przy tradycyjnej przynależności do Kościoła, przynależności egzekwowanej niekiedy autorytetem rodziców, nie prowadzi do rozwoju wiary młodych. Zawsze można dostrzec zobojętnienie wobec Kościoła w wieku, gdy młody człowiek wyzwala się spod wpływu i autorytetu rodziców, wówczas nie zawsze potrafi zrozumieć, dlaczego należy do Kościoła. Wtedy pomocą jest przyswojenie właściwej wizji Kościoła, jaką młodzi mogą otrzymać i przeżywać podczas katechezy ${ }^{69}$.

Ponieważ katechizacja jest jedną z podstawowych form posługi słowa w Kościele, dlatego jej celem jest wychowanie każdego wierzącego, jak również całej wspólnoty do pełnej dojrzałości chrześcijańskiej. Katecheza kształtować powinna więc najpierw człowieczeństwo, na którym wspiera się gmach łaski, pogłębiać wiarę, ukazać chrześcijański sens życia, rozwiązywać codzienne problemy w świetle Ewangelii, wreszcie, co jest również niezmiernie ważne i istotne, wprowadzać do świadomego uczestnictwa w życie Kościoła ${ }^{70}$.

Katecheza, której ostatecznym sensem jest uświęcanie wiernych, budowa wspólnoty Ludu Bożego i włączenie tego ludu do pełnego uczestnictwa w zbawczą misję Kościoła, nie może być tylko przekazaniem doktryny lub zespołu poglądów, nadających się do przedyskutowania wśród naukowców. Ten problem katechetyczny był już poruszany w tej pracy. Natomiast tu chcemy podkreślić, że głoszenie Ewangelii zmierza do przyjęcia zespołu wartości, które wewnętrznie mają kształtować uczestników katechez ${ }^{71}$. Katechizowani muszą dojść do przekonania, że do pełni człowieczeństwa nie wystarcza rozwój biologiczny i intelektualny, lecz całościowo-osobowościowy, mający tak wielkie szanse realizacji właśnie w Kościele ${ }^{72}$.

Katecheza również musi prowadzić do liturgii, w której najpełniej realizuje się rzeczywistość Kościoła i pełna przynależność do niego jego członków. Liturgia nie tylko głosi tajemnicę zbawienia, lecz również sprowadza ją na człowieka. W liturgii członkowie Kościoła uczestniczą aktualnie w tajemnicach Boga żywego, w liturgii Chrystus zmartwychwstały i uwielbiony, Głowa Mistycznego Ciała staje się obecny jako ten, który działa i zbawia przez Ducha Świętego ${ }^{73}$. Msza święta jest wspólną ofiarą, a Kościół to nie tylko papież, biskupi i kapłani, ale także społeczność tych, którzy należą do Chrystusa. A Kościół w liturgii to nie tylko ten powszechny, ale także ten hic et nunc, zebrany w domu Bożym pod przewodnictwem kapłana. Młody człowiek chrześcijanin musi poczuć się

\footnotetext{
${ }^{68}$ R. Murawski, dz. cyt., s. 251.

${ }^{69}$ J. Szarkowski, dz. cyt., s. 121.

${ }^{70}$ E. Rząsa, Zadania wychowawcze katechezy, Katecheta 37 (1993), s. 145.

${ }^{71}$ Tamże, s. 145.

${ }_{72}$ J. Szarkowski, dz. cyt., s. 122.

${ }^{73}$ M. Finke, dz. cyt., s. 40.
} 
członkiem Ludu Bożego - Kościoła. Jego przynależność do Kościoła ${ }^{74}$ musi się najpełniej uwidocznić w liturgicznym uczestnictwie.

Człowiek w swym człowieczeństwie jest stale w akcie trwania i przez sam fakt życia albo siebie kształtuje, albo niszczy. Chrześcijanin w spotkaniu z Jezusem Chrystusem w Kościele winien stawać się nie tylko innym, ale prawdziwym, pełniejszym człowiekiem. Chrystus przyszedł na świat, aby ukazać człowieka odnowionego, doskonałego, i poucza w Ewangelii, jak powinno realizować się wartości, które Bóg przeznaczył dla człowieka. Również Kościół hierarchiczny bierze chrześcijan w opiekę, aby obronić prawdziwy rozwój człowieka.

Działanie Boga i Jego odwieczny plan zbawienia realizuje się w tajemnicy Kościoła przez Jezusa Chrystusa, któremu służy i z mocy którego służy całemu Ludowi Bożemu również hierarchia Kościoła. Przynależność do Kościoła z wyboru i odpowiedzialność za Kościół łączą się ściśle z ukazywaniem wartości ewangelicznych, jako źródeł rozwoju i dopełniania człowieczeństwa ${ }^{75}$. Do kształtowania świadomości kościelnej zachęca papież Jan Paweł II w słowach:

Zwracam się [...] do wszystkich i do każdego z osobna, do Pasterzy i do wiernych, z gorącym napomnieniem, ażeby niestrudzenie czuwali, co więcej, starali się o coraz większe zakorzenienie w swym umyśle, sercu i życiu świadomości kościelnej, a więc świadomości tego, że są członkami Kościoła Jezusa Chrystusa i że uczestniczą w tajemnicy jego komunii oraz w jego apostolskiej i misyjnej mocy (ChL, nr 64).

Świadomość przynależności do Kościoła winna więc być kształtowana od początku życia człowieka. A środowiskami wychowania eklezjalnego winny być: rodzina chrześcijańska, szkoła, grupy katechetyczne i eklezjalne oraz sam Kościół. W tych środowiskach człowiek wzrasta do dojrzałej wiary i przez ukazywanie nowej wizji Kościoła świadomie staje się jego członkiem.

\section{Der Aufbau der Kirchengemeinschaft im heutigen Gesellschaft (Zusammenfassung)}

Eine wichtige Rolle beim Aufbau der Kirchengemeinschaft spielt die Gestaltung des konzilianten Bewusstseins über die Kirche und die Erziehung im Bewusstsein der Zugehörigkeit zur Kirche bei den Katechisierten. Deshalb will der Autor, indem er die allgemeine, konziliante Lehre über die Kirche berücksichtigt, darauf aufmerksam machen,

\footnotetext{
${ }^{74}$ Tamże, s. 41.

${ }^{75}$ J. Szarkowski, dz. cyt., s. 122.
} 
wie wichtig der Aufbau und die Entwicklung der katechesierten Gruppen als Glaubensgemeinschaft sind:

1. Gruppe von Katechisierten als Glaubensgemeinschaft;

2. Gestaltung des neuen Bewusstseins über die Kirche;

3. Erziehung im Bewusstsein der Zugehörigkeit zur Kirche.

Die kirchliche Erziehung soll in der christlichen Familie, Schule, im Religionsunterricht, in kirchlichen Gruppen und in der Kirche selbst stattfinden. In diesem Milieu wächst der Mensch zum reifen Glauben heran und wird bewusst zum Mitglied der Kirche. 